\title{
Subsistence harvest of ringed, bearded, spotted, and ribbon seals in Alaska is sustainable
}

\author{
Mark A. Nelson ${ }^{1}$, Lori T. Quakenbush ${ }^{1, *}$, Brian D. Taras ${ }^{1}$, Ice Seal Committee ${ }^{2}$ \\ ${ }^{1}$ Alaska Department of Fish and Game, Fairbanks, AK 99701, USA \\ ${ }^{2}$ North Slope Borough, Utqiaġvik, AK 99723, USA
}

\begin{abstract}
In 2012, climate-warming related decreases in sea ice led to listings of ringed Pusa hispida and bearded seals Erignathus barbatus as threatened under the United States Endangered Species Act (ESA) prior to evidence of population declines. These and 2 other ice-associated species (spotted Phoca largha and ribbon seals Histriophoca fasciata) are vital subsistence resources to coastal Alaska Native communities. ESA-related assessments concluded that subsistence removals (seals that were harvested as well as those that were struck and lost) were sustainable; however, limited data precluded a quantitative evaluation. Potential biological removal (PBR), defined as the maximum number of animals that can be removed from a stock while allowing the stock to reach or maintain its optimal sustainable size, is typically used to determine whether human-caused mortality is sustainable. Although developed to address commercial fisheries bycatch, PBR serves as a conservative measure of sustainability. We compiled annual subsistence removal of ice seals in Alaska between 1992 and 2014 for 41 of 55 ice seal hunting communities and used per capita (based on the 2015 human population) removal estimates from surveyed communities to estimate regional and statewide average removals. We used average per capita values of harvest, combined with struck and lost, for surveyed communities (average removals) to extrapolate to unsurveyed communities. To account for underreported harvest, we also extrapolated using maximum harvest values, providing a liberal estimate. Both the average and liberal estimates of removals were below PBR for all 4 species. Thus, the best available data indicate that subsistence hunting is currently sustainable for all 4 species of ice seals.
\end{abstract}

KEY WORDS: Erignathus barbatus $\cdot$ Pusa hispida $\cdot$ Phoca hispida $\cdot$ Phoca largha $\cdot$ Histriophoca fasciata $\cdot$ Ice seal $\cdot$ Potential biological removal $\cdot$ Struck and lost

\section{INTRODUCTION}

Ringed Pusa (also Phoca) hispida, bearded Erignathus barbatus, spotted Phoca largha, and ribbon Histriophoca fasciata seals, collectively called 'ice seals', inhabit the Bering, Chukchi, and Beaufort seas of Alaska, USA. Ice seals are vital resources to subsistence-dependent coastal Alaska Native communities (Fall 2014). They are primarily hunted by 55 communities within 5 geographic regions delineated by regional native governments and corporations: North Slope (North Slope Borough, NSB), Northwest Arctic (Maniilaq), Bering Strait (Kawerak), Yukon-Kusko-

*Corresponding author: lori.quakenbush@alaska.gov kwim Delta (Association of Village Council Presidents, AVCP), and Bristol Bay (Bristol Bay Native Association, BBNA) (see Fig. 1). Ringed, bearded, and spotted seals are widely used for food, and their skins are used for clothes, boat skins, and handicrafts. Ribbon seals are less common and less preferred for food, but their skins are used for clothing and handicrafts. All marine mammals in the United States are protected under the US Marine Mammal Protection Act (MMPA) of 1972, as amended, but their importance to coastal Alaska Natives for subsistence purposes is recognized by an exemption under Section 101(b) for a legal harvest by Alaska Natives (www.fws.gov/ecological-

(C) The authors 2019. Open Access under Creative Commons by Attribution Licence. Use, distribution and reproduction are unrestricted. Authors and original publication must be credited.

Publisher: Inter-Research · www.int-res.com 
services/es-library/pdfs/mmpa.pdf). Marine mammals are managed by stock, which is defined in the MMPA (Section 3 (11)) as '... a group of marine mammals of the same species or smaller taxa in a common spatial arrangement, that interbreed when mature.' There is no evidence to suggest stock structure exists within any of the ice seal species in Alaska, so for the purpose of determining the sustainability of subsistence harvests in Alaska, we treated each species as a single stock in Alaskan waters (Boveng et al. 2009, 2013, Cameron et al. 2010, Kelly et al. 2010). Understanding the annual subsistence removal (harvest as well as struck and lost) is a basic management necessity and important to ensure that the number of seals used for subsistence and cultural activities does not exceed what is sustainable.

Ice seals are co-managed by the National Marine Fisheries Service (NMFS) and the Ice Seal Committee (ISC) through an agreement signed in 2006 (ISC \& NMFS 2006), which was authorized under Section 119 of the MMPA. The fundamental obligation of comanagement is 'to conserve marine mammals and provide co-management of subsistence use by Alaska Natives' (MMPA Section 119, Marine Mammal Commission 2007). NMFS is mandated to (1) maintain and recover marine mammal populations to their optimum sustainable population size, (2) maintain populations as a significant functioning element in the ecosystem, and (3) maintain population levels that will allow sustainable subsistence harvests by Alaska Natives (ISC \& NMFS 2006). The ISC represents Alaska Natives, who have local and traditional knowledge of ice seals and are dedicated to the long-term sustainable harvest of ice seals for food, culture, and handicrafts (ISC \& NMFS 2006). The co-management agreement provides for 'full and equal participation by both Parties [NMFS and ISC] in decisions affecting the subsistence management of marine mammals, to the maximum extent allowed by law' (ISC \& NMFS 2006).

In 2012, ringed and bearded seals in Alaska were designated as threatened under the US Endangered Species Act (ESA) because predicted changes in sea ice modeled over the next century would cause them to decline (NOAA 2012a,b). At the time of listing there was no evidence that either species had declined or was declining, and subsistence removals were specifically identified as not a factor in the reasons to list. Species listed as threatened under the ESA are defined as 'depleted' and 'strategic' under the MMPA, which results in higher scrutiny during stock assessments. Few ice seals are killed by commercial fishing (i.e. bycatch) or are known to die by ship strikes (Muto et al. 2018). Although ice seals may be affected by pollution, contaminants, and competition for prey with fisheries, these factors are largely unquantified. The largest known source of human-caused mortality for ice seals is removals by Alaska Natives for subsistence. Here, we refer to 'harvested' seals as hunted seals that are successfully retrieved and 'struck and lost' seals as those that are killed during hunting but not successfully retrieved. Hence, 'subsistence removals' are the total number of both harvested and struck and lost seals. Subsistence hunting is protected under the MMPA and cannot be regulated unless the hunted species is declared depleted under the MMPA or listed under the ESA. Once depleted, however, harvest regulations could be promulgated pursuant to MMPA Section 101(b). Currently, harvest is unregulated for all 4 species of ice seals because harvest is considered sustainable (Boveng et al. 2009, 2013, NOAA $2012 \mathrm{a}, \mathrm{b})$ even though it has never been quantified. The threatened and depleted status of ringed and bearded seals heightens the need to document the magnitude and sustainability of subsistence hunting. Harvesting ice seals sustainably will protect the populations and the harvest for the people who depend upon them.

Potential biological removal (PBR) is defined in the MMPA as '...the maximum number of animals, not including natural mortalities, that may be removed from a marine mammal stock while allowing that stock to reach or maintain its optimum sustainable population.' Human-caused removals from a stock are considered sustainable when they are less than PBR (Barlow et al. 1995, Wade \& Angliss 1997, NMFS 2005, Moore \& Merrick 2011). Stock assessments are required to estimate PBR and human-caused mortality (see MMPA Section 117). Although PBR was originally proposed and is integral for managing the take of marine mammals by commercial fishing operations (see MMPA Section 118, Wade 1998), it is not prescribed for regulation of subsistence harvests. However, it can serve as a conservative measure of sustainability, and as such, may be used as a protective guideline for evaluating stocks for which subsistence harvest is the primary source of human-caused mortality.

In Alaska, subsistence harvest of ice seals has been quantified using household surveys. These surveys have been conducted by private and government entities; some surveys provided numbers of seals struck and lost. These data have never been synthesized to evaluate whether subsistence removals are sustainable. The purpose of the present paper was to 
(1) compile ice seal harvest survey data collected in Alaskan communities during 1992-2014, including information on the proportion struck and lost; (2) use the surveys to calculate an annual regional and statewide estimate of ice seal harvest plus struck and lost; and (3) calculate PBR for each species of ice seal and assess the sustainability of subsistence hunting.

\section{MATERIALS AND METHODS}

\subsection{Estimating harvest within communities}

Household surveys designed to document how many seals were harvested (and sometimes, struck and lost) were conducted by many government entities (NMFS, State of Alaska, NSB, Maniilaq, Kawerak, AVCP, and BBNA), Alaska Native Organizations (ISC and Alaska Native Harbor Seal Commission), and private contractors (Braund and Associates). Questionnaires used during household surveys differed slightly by surveying entity. However, all surveys were designed to estimate community-level harvest and included questions on how many seals were harvested over a 12 mo period, usually a calendar year. Surveys collected information about all 4 ice seal species in each sampled community, except for some surveys in the Bristol Bay region (Wolfe \& Mishler 1993, 1994, 1995, 1996, 1997, 1998, Wolfe \& Hutchinson-Scarbrough 1999, Wolfe 2001, Wolfe et al. 2002, 2003, 2004, 2005, 2006, 2008, 2009a,b), which only collected information on spotted seals. Data from surveys are available in a published scientific paper (Fall et al. 2013), a report (ISC 2017) on the ISC's website (www.north-slope.org/departments/wildlifemanagement/co-management-organizations/ice-sealcommittee), and in a searchable online database maintained by the Division of Subsistence of the Alaska Department of Fish and Game, named the 'Community Subsistence Information System' (www. adfg.alaska.gov/sb/CSIS/).

The sample of households surveyed within each community was used to estimate the communitylevel harvest for each species. Community-level harvest was estimated differently for small and large communities. Almost all sampled communities were small ( $84 \%$ had $<175$ households) with an average of 4.3 people household ${ }^{-1}$. A census was attempted in all small communities surveyed. The level of harvest of sampled households was assumed to be representative of households not sampled. Extrapolation was done by estimating the average harvest per household and then multiplying by the number of house- holds (e.g. Wolfe \& Mishler 1993, Ahmasuk \& Trigg 2007, Bacon et al. 2009, ISC 2017). In the 3 large (>1400 Alaska Natives) communities of Utqiagivik (formerly Barrow), Kotzebue, and Dillingham, sampling was stratified by households with low and high levels of harvest. Nome, the only other large community, has never been surveyed. Data were extrapolated to households not surveyed within each stratum, and then strata were summed to determine the community total (Wolfe \& Mishler 1993, Whiting 2006).

\subsection{Accounting for struck and lost seals}

To estimate the total number of seals removed, we had to account for seals that were struck and lost. Little is known about the survival of wounded seals; however, there is some evidence that survival is low for wounded Pacific walruses Odobenus rosmarus divergens (Fay et al. 1994). We assumed that wounded seals had lower survival and, when estimating removals, considered a seal struck by a bullet to have died.

Some community surveys included the number of struck and lost seals as reported by the hunters in addition to the number harvested (i.e. retrieved). When struck and lost data were available for a community, we added the number struck and lost to the number of seals harvested to estimate the number of removals. For communities that did not collect information on the number of seals struck and lost, we applied a correction that was estimated using the regional proportion of seals struck and lost. The regional proportion was calculated as the total number of seals struck and lost (pooled across years) divided by the total number of seals removed (harvest plus struck and lost; also pooled across years). Struck and lost information was not collected during any NSB survey; therefore, data from the nearest 2 regions (Maniilaq and Kawerak) were pooled to estimate the proportion of struck and lost for the NSB. Two adjacent regions, instead of one, were used to obtain reasonable sample sizes. In other regions, regional struck and lost proportions were applied to the harvests reported for surveys without struck and lost data to obtain estimates of removal. Thus, harvest data from all surveys used to estimate harvest were adjusted for seals that were struck and lost. We calculated statewide struck and lost proportions as the average of the regional proportions weighted by the number of seals removed by each region. We did not include the derived proportions for the NSB in 
the statewide proportions presented; however, we did calculate them with and without the NSB estimate and there was little difference (0.002).

\subsection{Statewide estimates of subsistence removal}

To estimate the statewide subsistence removal (harvest plus struck and lost) of ice seals, we first calculated the per capita rate of removal from sampled communities, as follows:

Per capita removals $=\frac{\text { Total no. seals removed year } x}{\# \text { Alaska Natives in community year } x}$

For each species in a surveyed community, average removal for 2015 was calculated as the mean per capita removal for all surveys in that community multiplied by the Alaska Native population (all ages) living in that community during 2015 as recorded by the US Census (https://factfinder.census.gov/faces/ nav/jsf/pages/index.xhtml). To estimate removal in 2015 for unsurveyed communities, we averaged the mean per capita values for surveyed communities within that region and multiplied this average by each community's population in 2015. We then added the removals for all communities within a region to obtain the regional estimate of average annual removal by species. Following the same procedure for average removal estimates, but to account for underreported harvest as well as uncertainties due to survey error and extrapolations to communities not surveyed, we also developed a worst-case scenario by using maximum harvest values reported during any year for which data were available; we call this the 'liberal' subsistence removal estimate.

\subsection{Trends in struck and lost and removal estimates}

We analyzed both struck and lost and removal data for trends and temporal patterns to determine if averaging struck and lost and per capita removal data across years was appropriate, and to see if there had been any significant changes in removal through the survey period (R Development Core Team 2018). We plotted each type of data against survey year and visually examined the data for patterns. We used generalized linear models (function 'glm') with binomial error structure and the logit link to analyze struck and lost proportions for statistically significant trends $(p<0.05)$ at the regional level (by pooling data across communities) and at the community level for communities with $>3$ surveys with struck and lost data. For removal (count) data, we used generalized linear models with quasi-Poisson error structure and the log link to perform trend analysis for communities with $>3$ surveys. For regions with sufficient data (i.e. BBNA spotted seal data and NSB bearded and ringed seal data) we assessed trends in removal at both the regional level and the community level using generalized linear mixed models ( $\mathrm{R}$ package 'Ime4', Bates et al. 2015; function 'glmer') with Poisson error structure and the log link. To analyze for trends in removal per capita data (continuous positive values), we used generalized linear models with gamma error structure and the inverse link.

\subsection{Quality control of subsistence data}

Methods to maximize the accuracy of community surveys included (1) surveying a reasonable number of households from each community (usually > 30\% of all households), (2) documenting details of how extrapolations and other calculations were made, (3) community outreach regarding the importance of accurate harvest reporting and how results would be used, (4) maintaining household confidentiality (results are only shared as community totals never by individual household), and (5) keeping surveys voluntary (households can decline to participate in the survey without consequences).

The effort and success of subsistence hunters can fluctuate greatly from year to year due to weather, ice conditions, availability of ice seals, employment, and gas prices. Therefore, communities were surveyed in consecutive years, when possible, to address the variability in subsistence removal, document its causes, and detect trends. Conducting surveys in the same communities in consecutive years also added efficiency by having trained surveyors in place and a community familiar with the process to facilitate survey approval.

\subsection{PBR and sustainability of harvest}

PBR was calculated for each species as:

$$
\mathrm{PBR}=N_{\min } \times 0.5 R_{\max } \times F_{\mathrm{r}}
$$

where $N_{\min }$ is the minimum population estimate, $R_{\max }$ is the the maximum rate of population increase, and $F_{\mathrm{r}}$ is a recovery factor to further allow for population growth when the population is declining or unknown. 
$N_{\min }$ is an estimate of the number of animals in a stock that accounts for the uncertainty in population estimates and provides a reasonable assurance that stock size is equal to or greater than $N_{\min }$. $N_{\min }$ is calculated as the $20^{\text {th }}$ percentile of a log-normal distribution based on an estimate of the number of animals in a stock (see Wade 1998 and NMFS 2016 for more information). When reliable estimates of abundance that include estimates of uncertainty are not available, as is the case for ice seals, other approaches may be used as the estimate of $N_{\min }$, as long as they provide the same level of assurance that the stock size is equal to or greater than that estimate. Estimates of $N_{\min }$ for all seal species were derived from aerial survey data (Muto et al. 2018).

Values for $R_{\max }$ and $F_{\mathrm{r}}$ have been chosen to lower PBR when population growth rates or status are not known (as for ice seals). An $R_{\max }$ of $12 \%$ was recommended as a default for pinnipeds by Wade (1998) and has been used for calculating PBR in stock assessment reports for ice seals (Barlow et al. 1995, NMFS 2005, Moore \& Merrick 2011). $F_{\mathrm{r}}$ is added to further protect population growth when deemed necessary. The default value for $F_{\mathrm{r}}$ can be as low as 0.1 (e.g. for endangered species) and as high as 1, when a population is at optimum level or when a population is not known to be decreasing and whose removal is primarily subsistence removal 'provided there have not been recent increases in the level of takes' (NMFS 2016). For populations of unknown population status (i.e. not known if declining, stable, or increasing), such as ringed, bearded, and spotted seals, $F_{\mathrm{r}}$ has been set at 0.5 to lower PBR, thus allowing for additional population growth (Barlow et al. 1995, Moore \& Merrick 2011). Recently, however, $F_{\mathrm{r}}$ for ribbon seals was set at 1.0, invoking the 'subsistence' provision described above because of no known population decline and consistent levels of subsistence harvest (Muto et al. 2018). We assessed the sustainability of the subsistence harvest of each seal species by comparing the statewide average and liberal removal estimates to PBR using the accepted default values for $R_{\max }$ and $F_{\mathrm{r}}$.

\subsection{Abundance estimates}

We used estimates of $N_{\text {min }}$ provided by Muto et al. (2018) for spotted (423 247) and ribbon (163086) seals from aerial surveys conducted in the Bering Sea in 2012 and 2013 that included most of their breeding range and were corrected for availability (Conn et al. 2014). For ringed seals, we combined the results of aerial surveys performed in 2 portions of their range to obtain an estimate of $N_{\min }$ of 470000 ringed seals for the US portion of the Bering, Chukchi, and Beaufort seas (see Table 7). Ringed seals were estimated to exceed 300000 for US portions of the Chukchi and Beaufort seas (Kelly et al. 2010, Muto et al. 2018). This value is considered a substantial underestimate due to the limited survey area and is therefore an appropriate $N_{\min }$ for that area. Similarly, ringed seals were estimated to exceed 170000 for the US portion of the Bering Sea, and this value is also considered a substantial underestimate because it did not account for availability bias or for seals on shorefast ice (Conn et al. 2014, Muto et al. 2018). For bearded seals, we combined the $N_{\min }$ estimated for the US Bering Sea (273676 seals corrected for availability bias; Conn et al. 2014, Muto et al. 2018) with an $N_{\min }$ we estimated from surveys conducted in the eastern Chukchi Sea in 1999 and 2000 (Bengtson et al. 2005). Bengtson et al. (2005) did not adjust bearded seal density estimates from aerial surveys for availability and, citing Krafft et al. (2000), noted that the correction factor could be as high as 12.5. Krafft et al. (2000) presented haul-out data from 4 lactating bearded seals near Svalbard collected during May, approximately the same time of year the surveys were performed. Upon review of these haul-out data, we noticed that the percent of time out of the water during the survey hours (07:30-15:30 h) was greater than the daily average. Therefore, we calculated a survey-windowspecific correction factor of 8.3 and applied it to the survey estimates, which yielded a mean abundance of 113597 seals and an $N_{\min }$ of 83652 bearded seals (i.e. the average of $N_{\min }=44566$ in 1999 and $N_{\min }=$ 122738 in 2000). Thus, for bearded seals we combined the estimate of $N_{\min }$ for the Bering Sea (273676 seals) with our estimate of $N_{\min }$ for the Chukchi Sea (83652 seals) for an overall $N_{\min }$ of 357328 . Note that our estimate of $N_{\min }$ does not include the Beaufort Sea where bearded seals also occur and breed.

\section{RESULTS}

\subsection{Community surveys}

The 7 coastal NSB communities were surveyed 2-7 times per community (Table 1). Most surveys were conducted by the NSB, Department of Wildlife Management. The 5 Maniilaq communities were surveyed 2-5 times (Table 2). Fifteen (of 17) Kawerak communities were surveyed 1-4 times (Table 3). Nome, the largest Kawerak community (with $28 \%$ of 
Table 1. Annual average and liberal subsistence removal estimates (harvest plus struck and lost) of ice seals for the 7 coastal communities in the North Slope Borough region based on household surveys conducted from 1992-2014. No surveys in the North Slope Borough region included struck and lost data; therefore this was estimated using the average estimate of the 2 adjacent regions (Maniilaq and Kawerak)

\begin{tabular}{|c|c|c|c|c|c|c|c|c|c|c|}
\hline \multirow{3}{*}{$\begin{array}{l}\text { Community } \\
\text { Atqasuk }^{\mathrm{c}}\end{array}$} & \multirow{3}{*}{$\begin{array}{l}\begin{array}{c}\text { No. of surveys } \\
\text { (no. with } \\
\text { struck and lost) }\end{array} \\
2(0)\end{array}$} & \multirow{3}{*}{$\begin{array}{c}\begin{array}{c}\text { Alaska Native } \\
\text { population } \\
2015\end{array} \\
240\end{array}$} & \multicolumn{2}{|c|}{ Ringed seals } & \multicolumn{2}{|c|}{ Bearded seals } & \multicolumn{2}{|c|}{ Spotted seals } & \multicolumn{2}{|c|}{ Ribbon seals } \\
\hline & & & & & & & & & & \\
\hline & & & 3 & 7 & 5 & 7 & 0 & 0 & 0 & 0 \\
\hline Utqiag்vik (Barro & $\mathrm{ow})^{\mathrm{c}-\mathrm{e}} 7(0)$ & 2760 & 465 & 666 & 713 & 1318 & 39 & 120 & 0 & 0 \\
\hline Kaktovik $^{\mathrm{c}, \mathrm{d}, \mathrm{f}}$ & $4(0)$ & 244 & 19 & 42 & 18 & 23 & 6 & 11 & 0 & 0 \\
\hline Nuiqsut $^{\mathrm{c}-\mathrm{e}}$ & $6(0)$ & 416 & 74 & 185 & 13 & 29 & 3 & 8 & 0 & 0 \\
\hline Point Hope ${ }^{c, d, g}$ & $4(0)$ & 701 & 472 & 1208 & 112 & 191 & 15 & 55 & 0 & 0 \\
\hline Point Lay ${ }^{\mathrm{c}, g}$ & $3(0)$ & 285 & 33 & 57 & 48 & 63 & 14 & 29 & 0 & 0 \\
\hline Wainwright ${ }^{\mathrm{c}, \mathrm{d}, \mathrm{f}}$ & $3(0)$ & 580 & 80 & 179 & 122 & 189 & 12 & 22 & 0 & 0 \\
\hline Total & $29(0)$ & 5226 & 1146 & 2343 & 1031 & 1820 & 89 & 245 & 0 & 0 \\
\hline \multicolumn{11}{|c|}{ 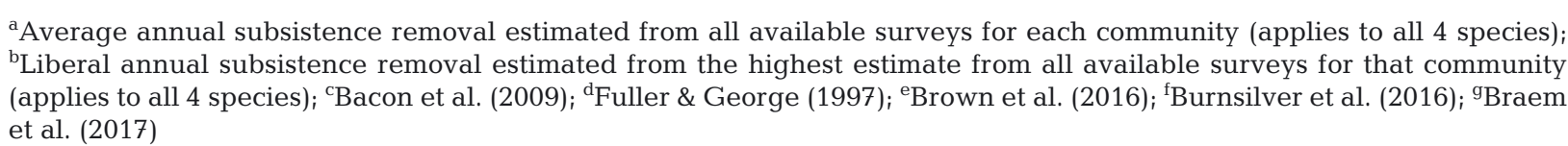 } \\
\hline
\end{tabular}

Table 2. Annual average and liberal subsistence removal estimates (harvest plus struck and lost) of ice seals for 5 communities in the Maniilaq region based on household surveys conducted from 1992-2014

\begin{tabular}{|c|c|c|c|c|c|c|c|c|c|c|}
\hline \multirow[t]{2}{*}{ Community } & \multirow{2}{*}{$\begin{array}{l}\text { No. of surveys } \\
\text { (no. with } \\
\text { struck and lost) }\end{array}$} & \multirow{2}{*}{$\begin{array}{c}\text { Alaska Native } \\
\text { population } \\
2015\end{array}$} & \multicolumn{2}{|c|}{ Ringed seals } & \multicolumn{2}{|c|}{ Bearded seals } & \multicolumn{2}{|c|}{ Spotted seals } & \multicolumn{2}{|c|}{ Ribbon seals } \\
\hline & & & Average $^{a}$ & ${ }^{a}$ Liberal $^{\mathrm{b}}$ & Average & Liberal & Average & Liberal & Average & Liberal \\
\hline Buckland $d^{\mathrm{c}, \mathrm{d}}$ & $2(1)$ & 432 & 42 & 58 & 89 & 130 & 95 & 104 & 2 & 5 \\
\hline Deering $^{\mathrm{d}-\mathrm{f}}$ & $3(1)$ & 127 & 5 & 8 & 49 & 64 & 12 & 25 & 0 & 0 \\
\hline Kivalina $^{\mathrm{d}, \mathrm{g}, \mathrm{h}}$ & $3(1)$ & 388 & 80 & 147 & 187 & 251 & 22 & 41 & 4 & 11 \\
\hline Kotzebue $^{\mathrm{f}, \mathrm{g}, \mathrm{i}}$ & $5(0)$ & 2435 & 363 & 1217 & 659 & 1285 & 369 & 637 & 1 & 4 \\
\hline Noatak $^{\mathrm{d}, \mathrm{h}, \mathrm{j}}$ & $3(1)$ & 443 & 2 & 6 & 52 & 56 & 8 & 22 & 0 & 1 \\
\hline Total & $16(4)$ & 3825 & 493 & 1436 & 1038 & 1786 & 507 & 829 & 9 & 20 \\
\hline
\end{tabular}

the region's population), was not surveyed. Solomon, the only other Kawerak community not surveyed, had a population of 4 . Eight (of 20) AVCP communities were surveyed 1-9 times (Table 4). These 8 communities accounted for $49 \%$ of the population in the AVCP region and had population sizes fairly representative of the region's other communities. All 6 communities within the northern BBNA region were surveyed at least once for all 4 ice seals, and Togiak and Twin Hills (locations 54 and 55 in Fig. 1) were surveyed 6 and 5 times, respectively (Table 5). All BBNA communities were surveyed for spotted seals during a long-term (15-20 yr) harbor seal and sea lion survey conducted jointly by the Alaska Department of Fish and Game and the Alaska Native Harbor
Seal Commission (Wolfe \& Mishler 1993, 1994, 1995, 1996, 1997, 1998, Wolfe \& Hutchinson-Scarbrough 1999, Wolfe 2001, Wolfe et al. 2002, 2003, 2004, 2005, 2006, 2008, 2009a,b).

\subsection{Struck and lost}

Of 128 surveys that collected harvest information for all 4 species, 68 (53\%) also collected struck and lost information. Another 88 surveys collected harvest information on spotted seals only, all of which included struck and lost. Except for NSB, all regions had at least 4 surveys that included struck and lost information. 
Table 3. Annual average and liberal subsistence removal estimates (harvest plus struck and lost) of ice seals for 17 communities in the Kawerak region based on household surveys conducted from 1993-2014. Estimates for communities with no surveys during the study period were extrapolated from the rest of the region (shaded rows)

\begin{tabular}{|c|c|c|c|c|c|c|c|c|c|c|}
\hline \multirow{3}{*}{$\begin{array}{l}\text { Community } \\
\text { Brevig Mission }^{\mathrm{c}-\mathrm{e}}\end{array}$} & \multirow{3}{*}{$\begin{array}{l}\begin{array}{c}\text { No. of surveys } \\
\text { (no. with }\end{array} \\
\text { struck and lost) }\end{array}$} & \multirow{3}{*}{$\begin{array}{c}\text { Alaska Native } \\
\text { population } \\
2015\end{array}$} & \multicolumn{2}{|c|}{ Ringed seals } & \multicolumn{2}{|c|}{ Bearded seals } & \multicolumn{2}{|c|}{ Spotted seals } & \multicolumn{2}{|c|}{ Ribbon seals } \\
\hline & & & Average $^{a}$ & Liberal $^{\mathrm{b}}$ & Average & Liberal & Average & Liberal & Average & Liberal \\
\hline & & & 102 & 193 & 85 & 124 & 129 & 183 & 11 & 32 \\
\hline Elim $^{\mathrm{d}, \mathrm{e}}$ & $2(2)$ & 339 & 31 & 49 & 60 & 74 & 19 & 22 & 1 & 1 \\
\hline Gambell ${ }^{\mathrm{c}-\mathrm{e}}$ & $3(3)$ & 699 & 441 & 796 & 738 & 1209 & 631 & 951 & 27 & 40 \\
\hline Golovin ${ }^{\mathrm{c}, \mathrm{d}, \mathrm{f}}$ & $3(2)$ & 160 & 31 & 86 & 19 & 34 & 28 & 52 & 2 & 4 \\
\hline Koyuk $^{\mathrm{e}}$ & $1(1)$ & 365 & 9 & 9 & 12 & 12 & 28 & 28 & 0 & 0 \\
\hline Little Diomede $\mathrm{f}^{\mathrm{f}}$ & $1(0)$ & 118 & 33 & 33 & 39 & 39 & 34 & 34 & 0 & 0 \\
\hline Nome & $0(0)$ & 2263 & 632 & 1152 & 898 & 1370 & 877 & 1304 & 36 & 69 \\
\hline Savoonga $^{\mathrm{c}-\mathrm{e}, \mathrm{g}}$ & $4(3)$ & 704 & 367 & 679 & 406 & 754 & 416 & 896 & 29 & 53 \\
\hline Shaktoolik $^{\mathrm{c}, \mathrm{d}}$ & $2(2)$ & 258 & 68 & 122 & 67 & 85 & 49 & 52 & 1 & 1 \\
\hline Shishmaref ${ }^{\mathrm{e}, \mathrm{f}, \mathrm{h}}$ & $3(1)$ & 605 & 405 & 593 & 547 & 683 & 640 & 777 & 12 & 21 \\
\hline Solomon & $0(0)$ & 4 & 1 & 2 & 2 & 2 & 2 & 2 & 0 & 0 \\
\hline St. Michael ${ }^{\mathrm{d}, \mathrm{e}}$ & $2(2)$ & 412 & 2 & 3 & 34 & 49 & 45 & 50 & 0 & 0 \\
\hline Stebbins $^{\mathrm{c}-\mathrm{f}}$ & $4(3)$ & 571 & 92 & 317 & 91 & 199 & 52 & 86 & 1 & 5 \\
\hline Teller ${ }^{\mathrm{d}, \mathrm{e}}$ & $2(2)$ & 235 & 22 & 45 & 38 & 67 & 66 & 103 & 1 & 3 \\
\hline Unalakleet $^{\mathrm{e}}$ & $1(1)$ & 706 & 10 & 10 & 90 & 90 & 119 & 119 & 3 & 3 \\
\hline Wales $^{\mathrm{d}, \mathrm{e}, \mathrm{i}}$ & $3(2)$ & 149 & 39 & 77 & 66 & 108 & 20 & 40 & 6 & 18 \\
\hline White Mountain ${ }^{\mathrm{e}}$ & $1(1)$ & 203 & 1 & 1 & 58 & 58 & 20 & 20 & 0 & 0 \\
\hline Total & $35(28)$ & 8189 & 2287 & 4167 & 3248 & 4957 & 3175 & 4720 & 130 & 250 \\
\hline
\end{tabular}

Sample sizes for BBNA (spotted seals) and AVCP (ringed, bearded, and spotted seals) surveys were sufficient for trend analysis. At the regional level, the proportions struck and lost showed no consistent patterns over the study period and no statistically significant trends, thus averaging struck and lost data across years within regions was justified. Statewide, the average proportion of struck and lost ranged from 0.062 for ringed seals to 0.125 for spotted seals (Table 6).

\subsection{Average and liberal statewide removal estimates}

Estimates of annual subsistence removal (including struck and lost) from 41 surveyed communities were extrapolated to communities without surveys to provide estimates for 55 ice seal hunting communities at both an average and liberal level (Tables 1-6). Based on average harvest, Kawerak had the highest subsistence removal for 3 of the 4 ice seal species and was a close second to AVCP for ringed seals (Table 6). BBNA had the lowest subsistence removal for ringed and bearded seals, NSB had the lowest subsistence removal for spotted seals; BBNA and NSB did not harvest ribbon seals (Table 6). The average statewide subsistence removal was highest for bearded seals, followed by ringed, spotted, and then ribbon seals (Table 6).

Sample sizes were sufficient for regional trend analysis for BBNA spotted seals and for NSB ringed and bearded seals. In these cases, the number of seals removed showed no consistent patterns through time and exhibited no statistically significant trends. Four communities had statistically significant trends in seals removed and per capita removal, all of which were negative (Togiak, Dillingham, and Twin Hills for spotted seals and Kotzebue for bearded and ringed seals). Except for the aforementioned trends, averaging the per capita removal estimates across years within regions was justified. Including the negative trends in per capita removal at the community level in the overall average resulted in a slight overestimate of removal, which is consistent with our conservative approach for evaluating subsistence take relative to PBR. 
Table 4. Annual average and liberal subsistence removal estimates (harvest plus struck and lost) of ice seals for 20 communities in the Yukon-Kuskokwim Delta region (Association of Village Council Presidents) based on household surveys conducted from 1998-2014. Estimates for communities with no surveys during the study period were extrapolated from the rest of the region (shaded rows)

\begin{tabular}{|c|c|c|c|c|c|c|c|c|c|c|}
\hline \multirow{3}{*}{$\begin{array}{l}\text { Community } \\
\text { Alakanukc }^{c}\end{array}$} & \multirow{3}{*}{$\begin{array}{c}\begin{array}{c}\text { No. of surveys } \\
\text { (no. with }\end{array} \\
\text { struck and lost) }\end{array}$} & \multirow{3}{*}{$\begin{array}{c}\text { Alaska Native } \\
\text { population } \\
2015 \\
758\end{array}$} & \multirow{2}{*}{\multicolumn{2}{|c|}{$\begin{array}{c}\text { Ringed seals } \\
\text { Average }^{\mathrm{a}} \text { Liberal }^{\mathrm{b}}\end{array}$}} & \multicolumn{2}{|c|}{ Bearded seals } & \multicolumn{2}{|c|}{ Spotted seals } & \multicolumn{2}{|c|}{ Ribbon seals } \\
\hline & & & & & Average & Liberal & Average & Liberal & Average & Liberal \\
\hline & & & 15 & 15 & 132 & 132 & 46 & 46 & 0 & 0 \\
\hline Chefornak & $0(0)$ & 454 & 109 & 159 & 60 & 86 & 53 & 74 & 1 & 2 \\
\hline Chevak & $0(0)$ & 1060 & 255 & 372 & 140 & 201 & 124 & 173 & 2 & 5 \\
\hline Eek $^{\mathrm{d}}$ & $1(0)$ & 321 & 13 & 13 & 17 & 17 & 24 & 24 & 0 & 0 \\
\hline Emmonak $^{\mathrm{e}-\mathrm{h}}$ & $4(3)$ & 813 & 72 & 140 & 126 & 183 & 43 & 55 & 4 & 7 \\
\hline Goodnews Bay & $0(0)$ & 266 & 64 & 93 & 35 & 50 & 31 & 43 & 1 & 1 \\
\hline Hooper Bay ${ }^{\mathrm{e}, \mathrm{f}, \mathrm{I}}$ & $9(9)$ & 1189 & 558 & 951 & 183 & 355 & 77 & 154 & 1 & 5 \\
\hline Kipnuk & $0(0)$ & 686 & 165 & 241 & 90 & 130 & 80 & 112 & 2 & 3 \\
\hline Kongiganak & $0(0)$ & 408 & 98 & 143 & 54 & 77 & 48 & 67 & 1 & 2 \\
\hline Kotlik & $0(0)$ & 619 & 149 & 217 & 82 & 117 & 72 & 101 & 1 & 3 \\
\hline Kwigillingok & $0(0)$ & 331 & 80 & 116 & 44 & 63 & 39 & 54 & 1 & 2 \\
\hline Mekoryuk & $0(0)$ & 199 & 48 & 70 & 26 & 38 & 23 & 33 & 0 & 1 \\
\hline Nightmute & $0(0)$ & 302 & 73 & 106 & 40 & 57 & 35 & 49 & 1 & 1 \\
\hline Nunam Iqua & $0(0)$ & 202 & 49 & 71 & 27 & 38 & 24 & 33 & 0 & 1 \\
\hline Platinum & $0(0)$ & 66 & 16 & 23 & 9 & 13 & 8 & 11 & 0 & 0 \\
\hline Quinhagak ${ }^{\mathrm{e}, \mathrm{f}, \mathrm{g}}$ & $8(8)$ & 698 & 118 & 169 & 39 & 80 & 142 & 265 & 1 & 3 \\
\hline Scammon Bay ${ }^{\mathrm{d}, \mathrm{g}}$ & $3(2)$ & 525 & 164 & 178 & 73 & 89 & 56 & 60 & 4 & 7 \\
\hline Toksook Bay & $0(0)$ & 657 & 158 & 230 & 87 & 125 & 77 & 107 & 1 & 3 \\
\hline Tuntutuliak $^{\mathrm{d}}$ & $1(0)$ & 466 & 89 & 89 & 66 & 66 & 134 & 134 & 0 & 0 \\
\hline Tununak $^{g}$ & $5(5)$ & 294 & 189 & 221 & 32 & 38 & 70 & 89 & 0 & 2 \\
\hline Total & $32(27)$ & 10314 & 2484 & 3617 & 1360 & 1954 & 1205 & 1685 & 23 & 47 \\
\hline
\end{tabular}

Table 5. Annual average and liberal subsistence removal estimates (harvest plus struck and lost) of ice seals for 6 communities in the Bristol Bay Native Association region based on household surveys conducted from 1992-2011

\begin{tabular}{|c|c|c|c|c|c|c|c|c|c|c|c|}
\hline \multirow[t]{2}{*}{ Community } & \multicolumn{2}{|c|}{$\begin{array}{l}\text { No. of surveys } \\
\quad \text { (no. with } \\
\text { struck and lost) }\end{array}$} & \multirow[t]{2}{*}{$\begin{array}{l}\text { Alaska Native } \\
\text { population } \\
2015\end{array}$} & \multicolumn{2}{|c|}{$\begin{array}{c}\text { Ringed seals } \\
\text { Average }^{\mathrm{a}} \text { Liberal }^{\mathrm{b}}\end{array}$} & \multicolumn{2}{|c|}{ Bearded seals } & \multicolumn{2}{|c|}{ Spotted seals } & \multicolumn{2}{|c|}{ Ribbon seals } \\
\hline & $\begin{array}{c}\text { All } \\
\text { seals }\end{array}$ & $\begin{array}{l}\text { Spotted } \\
\text { only }\end{array}$ & & & & & & & & & \\
\hline Aleknagik ${ }^{\mathrm{c}-\mathrm{s}}$ & $1(0)$ & $16(16)$ & 224 & 0 & 0 & 0 & 0 & 16 & 44 & 0 & 0 \\
\hline Clark's Point ${ }^{\mathrm{C}-\mathrm{s}}$ & $1(0)$ & $16(16)$ & 64 & 23 & 23 & 0 & 0 & 19 & 80 & 0 & 0 \\
\hline Dillingham ${ }^{\mathrm{c}-\mathrm{r}, \mathrm{t}}$ & $1(0)$ & $17(16)$ & 1492 & 4 & 4 & 9 & 9 & 31 & 114 & 0 & 0 \\
\hline Manokotak $^{\mathrm{c}-\mathrm{s}}$ & $2(0)$ & $17(16)$ & 3 & 15 & 26 & 15 & 18 & 34 & 79 & 0 & 0 \\
\hline $\operatorname{Togiak}^{\mathrm{c}-\mathrm{r}, \mathrm{u}, \mathrm{v}}$ & $6(5)$ & $20(19)$ & 850 & 2 & 6 & 6 & 29 & 159 & 433 & 0 & 0 \\
\hline Twin Hills ${ }^{\mathrm{c}-\mathrm{r}, \mathrm{u}, \mathrm{v}}$ & $5(4)$ & $15(14)$ & 95 & 1 & 3 & 0 & 0 & 19 & 55 & 0 & 0 \\
\hline Total & $16(9)$ & $101(97)$ & 3178 & 44 & 62 & 30 & 56 & 277 & 805 & 0 & 0 \\
\hline \multicolumn{12}{|c|}{ 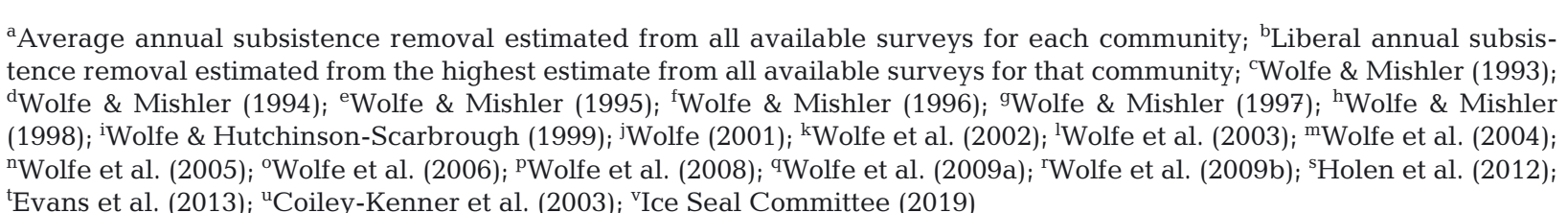 } \\
\hline
\end{tabular}




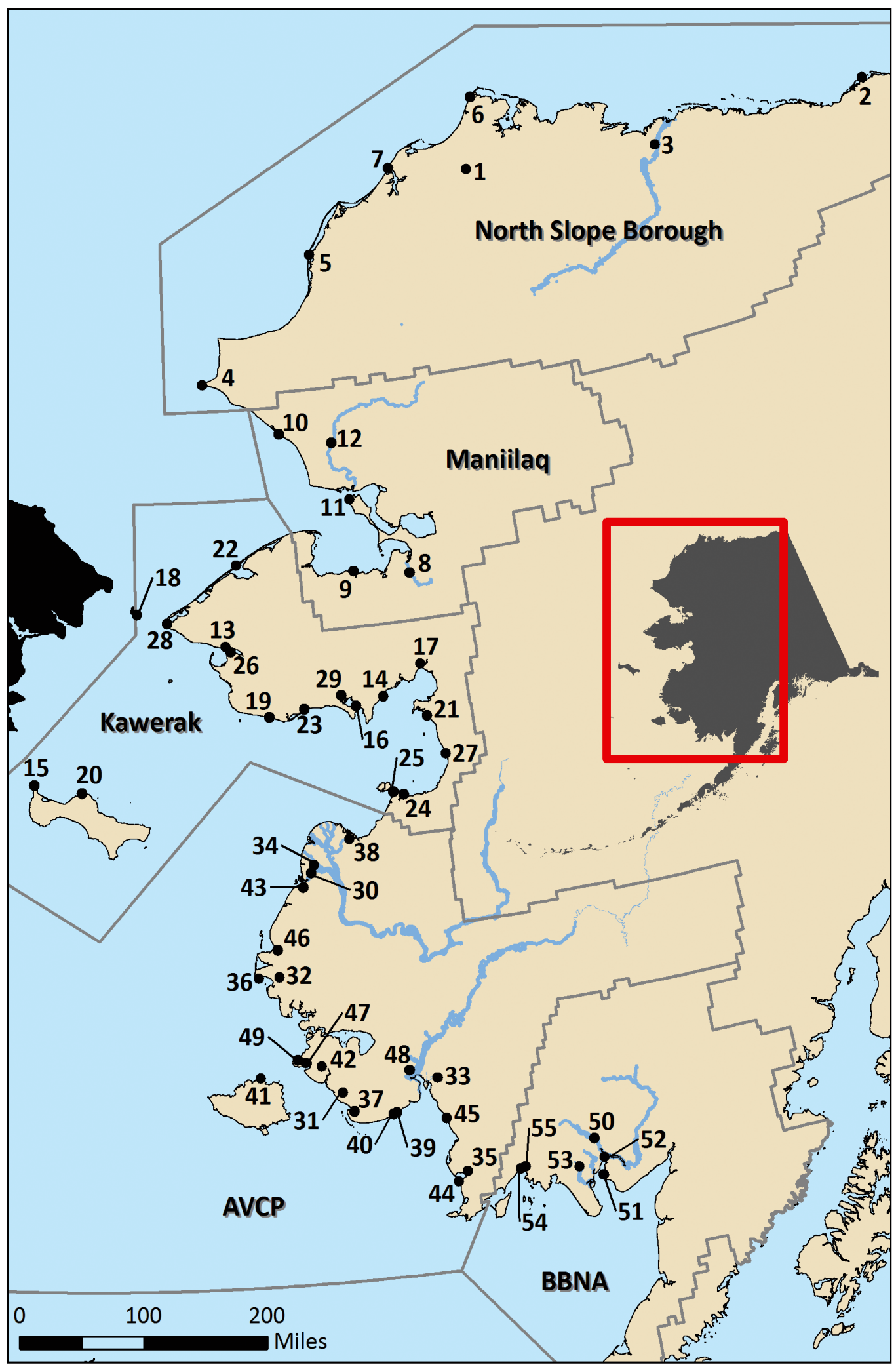

North Slope Borough

Atqasuk

Kaktovik

Nuiqsut

Point Hope

Point Lay

Utqiag்vik (Barrow) 6

Wainwright 7

Maniilaq

Buckland

Deering

Kivalina

Kotzebue

Noatak

Kawerak

Brevig Mission 13

Elim

Gambell

Golovin

Koyuk

Little Diomede 18

Nome 19

Savoonga 20

Shaktoolik 21

Shishmaref 22

Solomon 23

St. Michael 24

Stebbins $\quad 25$

Teller $\quad 26$

Unalakleet 27

Wales 28

White Mountain 29

AVCP

Alakanuk $\quad 30$

Chefornak 31

Chevak 32

Eek 33

Emmonak 34

Goodnews Bay 35

Hooper Bay $\quad 36$

Kipnuk 37

Kotlik 38

Kongiganak $\quad 39$

Kwigillingok $\quad 40$

Mekoryuk $\quad 41$

Nightmute $\quad 42$

Nunam Iqua $\quad 43$

Platinum 44

Quinhagak $\quad 45$

Scammon Bay $\quad 46$

Toksook Bay 47

Tuntutuliak 48

Tununak 49

BBNA

Aleknagik $\quad 50$

Clark's Point 51

Dillingham $\quad 52$

Manokotak 53

Togiak $\quad 54$

Twin Hills $\quad 55$

Fig. 1. The 5 regions and 55 communities where Alaska Native hunters regularly hunt ice seals for subsistence in Alaska. Numbers associated with each community correspond to the communities' location on the map. AVCP: Association of Village Council Presidents; BBNA: Bristol Bay Native Association 
Table 6. Annual average and liberal subsistence removal estimates (harvest plus struck and lost) of ice seals by region and the average proportion struck and lost ('Lost') for each region. Totals include estimated seal removal by subsistence hunters statewide with the average statewide estimate of struck and lost for each species. The North Slope Borough (NSB) did not collect struck and lost information during their surveys. Shaded cells are the average of Maniilaq and Kawerak struck and lost estimates. This derived value was not used when calculating the statewide average proportions struck and lost. AVCP: Association of Village Council Presidents; BBNA: Bristol Bay Native Association

\begin{tabular}{|c|c|c|c|c|c|c|c|c|c|c|c|c|}
\hline \multirow{3}{*}{$\begin{array}{l}\text { Region } \\
\text { NSB }\end{array}$} & \multirow{2}{*}{\multicolumn{3}{|c|}{$\begin{array}{c}\text { Ringed seals } \\
\text { Average }^{\mathrm{a}} \text { Liberal }^{\mathrm{b}} \text { Lost }^{\mathrm{c}}\end{array}$}} & \multicolumn{3}{|c|}{ Bearded seals } & \multicolumn{3}{|c|}{ Spotted seals } & \multicolumn{3}{|c|}{ Ribbon seals } \\
\hline & & & & \multicolumn{2}{|c|}{ Average Liberal } & \multirow{2}{*}{$\begin{array}{l}\text { Lost } \\
0.098\end{array}$} & \multicolumn{2}{|c|}{ Average Liberal } & \multirow{2}{*}{$\begin{array}{l}\text { Lost } \\
0.096\end{array}$} & \multicolumn{2}{|c|}{ Average Liberal } & \multirow[t]{2}{*}{ Lost } \\
\hline & 1146 & 2343 & 0.079 & 1031 & 1820 & & 89 & 245 & & 0 & 0 & \\
\hline Maniilaq & 493 & 1436 & 0.095 & 1038 & 1786 & 0.097 & 507 & 829 & 0.111 & 9 & 20 & 0.128 \\
\hline Kawerak & 2287 & 4167 & 0.078 & 3248 & 4957 & 0.098 & 3175 & 4720 & 0.095 & 130 & 250 & 0.057 \\
\hline AVCP & 2484 & 3617 & 0.054 & 1360 & 1954 & 0.111 & 1205 & 1685 & 0.109 & 23 & 47 & 0.137 \\
\hline BBNA & 44 & 62 & 0.083 & 30 & 56 & 0.200 & 277 & 805 & 0.170 & 0 & 0 & \\
\hline Statewide total & 6454 & 11625 & & 6707 & 10573 & & 5253 & 8284 & & 162 & 317 & \\
\hline Weighted average & & & 0.062 & & & 0.102 & & & 0.125 & & & 0.071 \\
\hline
\end{tabular}

Table 7. Total annual (average and liberal) statewide removal estimates (harvest plus struck and lost), and potential biological removal (PBR) for ringed, bearded, spotted, and ribbon seals. Human-caused removals of < PBR are a conservative indicator that the removal is sustainable

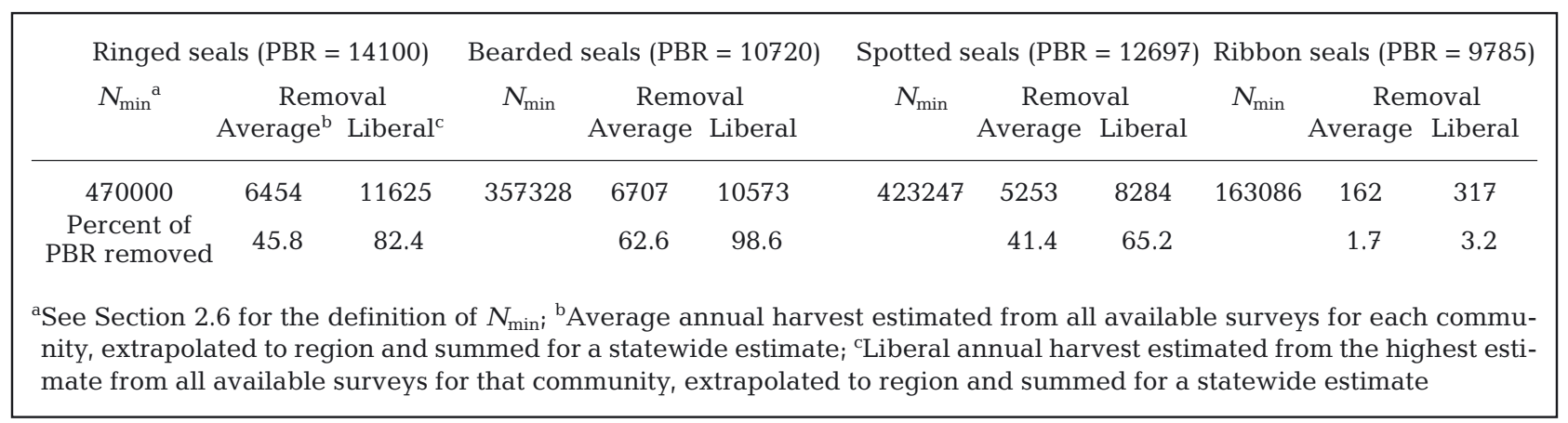

\subsection{Sustainability of the subsistence harvest}

Although PBR was originally proposed to evaluate commercial fishery bycatch and is not prescribed for regulating subsistence harvest, we applied it as a conservative measure of sustainability. To this end, removals of less than PBR can be used to represent conservative measures of sustainable take. The average annual subsistence removal was less than PBR for all 4 species, ranging from $1.7 \%$ of PBR for ribbon seals to $62.6 \%$ of PBR for bearded seals (Table 7). The liberal, or worst-case annual subsistence removal was also less than PBR for all species, ranging from $3.2 \%$ of PBR for ribbon seals to $98.6 \%$ of PBR for bearded seals (Table 7).

\section{DISCUSSION}

\subsection{Sustainability of subsistence hunting}

Human-caused removals of marine mammals are not considered to be problematic if the population can remain stable or grow despite those removals. PBR has been used to assess whether human-caused removals are sustainable. Using our liberal (worstcase) scenario, where removals are overestimated and abundance is underestimated, we found that annual liberal removals due to subsistence hunting were less than PBR for all 4 seal species (Table 7). Even though liberal subsistence removals were $98.6 \%$ of PBR for bearded seals, the conservatism 
built into our calculations reduces cause for concern. Recall that the minimum abundance estimate for bearded seals did not include half of the Bering Sea, half of the Chukchi Sea, or any of the Beaufort Sea.

\subsection{Limitations to estimating statewide annual subsistence removal}

Documenting ice seal harvest by interviewing participating households using a questionnaire designed to document how many seals were harvested in the prior 12 mo and, sometimes, how many were struck and lost, is not ideal, as numbers may not be remembered accurately. In coastal Alaskan communities, however, seals are important for food, and hunters often share their catch with other families, which makes the number harvested more likely to be remembered. Although the reporting period is 12 mo, most hunting occurs in spring and fall. For example, bearded seals are large and highly favored, and it is likely that hunters remember how many they caught in the spring and fall of the previous year, especially in communities that need skins for boat covers. Similarly, the hunters are also likely to remember seals that got away (i.e. were shot at and not retrieved) in the previous spring and fall seasons.

The reported number of seals struck and lost, however, is difficult to interpret. World-wide, self-reporting of struck and lost animals is generally viewed with suspicion, in part because consequences of higher reported struck and lost often result in reductions of the allowable harvest, such that hunters are believed to likely underreport losses to protect their quota. Struck and lost data that are not self-reported, however, are nearly impossible to collect. During this study (1992-2014), the percentage struck and lost reported for bearded seals in 128 surveys averaged $10.2 \%$ (range $9.7-20.0 \%$ per region). This was lower than estimates of $25-50 \%$ based upon information from the 1960s and 1970s for bearded seals in Alaska (Burns 1967, Burns \& Frost 1983). Studies that have addressed struck and lost in other marine mammals report similar findings. Fay et al. (1994) reported $42 \%$ lost for Pacific walruses, and Sjare \& Stenson (2002) reported $0-22 \%$ for harp seals on ice and 5-50\% for harp seals in the water; although it is difficult to know how comparable these results are to ours due to differences in behavior of the species and particulars of each hunt.

Although there was no consistent pattern of struck and lost at the regional level, some BBNA and AVCP communities exhibited significant trends in the pro- portion of struck and lost. For bearded and ringed seals all trends were negative and, because our regional proportions do not account for these trends, our estimates of removal could be slightly biased high, which is consistent with our conservative approach for evaluating subsistence take relative to PBR.

Predicting how struck and lost might have changed since the 1970s is also problematic. More hunting in open water could increase the chances of seals sinking, and a shorter spring hunting season (Huntington et al. 2017) may encourage riskier shots. On the other hand, more powerful and accurate firearms, faster boats, and efforts to reduce loss through hunter education (Ahmasuk 2006, Quakenbush et al. 2007) may decrease loss. Regardless, the number of seals reported by hunters as struck and lost are not likely to be lower than the $10 \%$ reported in our study. Until more current and specific information is available, struck and lost between 10 and $50 \%$ is the best available estimate.

We recognize that extrapolating harvest data from surveyed communities to communities not surveyed, which occurred in 2 regions, required caution because of the potential to introduce bias. We only extrapolated subsistence removal within a region, to minimize potential bias associated with differences among regions. For example, spotted seals are mostly hunted during the open water season and thus are available longer in the southern BBNA region than in regions farther north because sea ice leaves sooner and forms later. Thus, extrapolating among regions might bias estimates. Although only 8 of 20 communities in the AVCP region were surveyed, those 8 communities represented $49 \%$ of the region's human population, and population sizes were fairly representative of all the region's communities, which makes these extrapolations somewhat robust to bias. On the other hand, bias may have resulted from not surveying Nome, the largest community in the Kawerak region. It is possible that subsistence removal of ice seals in Nome is different than in smaller communities because Nome has a larger economy including more job opportunities and more grocery options (https://factfinder.census.gov/ faces/nav/jsf/pages/index.xhtml) that could lead to less dependence on seals for food. If per capita subsistence removal in Nome is less than in the smaller Kawerak communities, then we may have overestimated harvest for the entire Kawerak region by using the regional per capita estimate for the extrapolation.

We also presented a liberal subsistence removal estimate in addition to the average so as to purposely overestimate subsistence removal and better under- 
stand the level of sustainability. If worst-case estimates had exceeded PBR, a closer examination would be warranted.

\subsection{Setting recovery factors and estimating $P B R$}

It appears that setting $F_{r}$ at 0.5 for ringed, bearded, and spotted seals, when their populations are not known to be declining and human-caused mortality is primarily harvest by subsistence hunters, has been overly conservative. The Guidelines for Assessing Marine Mammal Stocks (GAMMS) state 'stocks that are not known to be decreasing taken primarily by aboriginal subsistence hunters, could have higher $F_{r}$ values [higher than $F_{r}=0.50$ ], up to and including 1.0, provided there have not been recent increases in the levels of takes' (NMFS 2016, p. 8). This logic was used to set the recovery factor for ribbon seals to 1.0 (Peter Boveng pers. comm.). Like ribbon seals, there is no evidence that the populations of bearded, ringed, and spotted seals are declining, so there is little justification for using values of $F_{r}$ other than 1 . In fact, evidence supports healthy populations (Quakenbush et al. 2009, Crawford et al. 2015) and their circumstances would appear to fit the logic used for setting the $F_{r}$ for ribbon seals. If $F_{r}$ is also set to 1.0 for ringed, bearded, and spotted seals, then subsistence removal of all 4 species would be well below their recommended PBRs.

Bearded and ringed seals differ from spotted and ribbon seals in that they are ESA-listed as threatened; however, the GAMMS provides for modifying the default recovery values for listed species, stating 'Recovery factors for ESA-listed stocks can be changed from their default values, but only after careful consideration and where available scientific evidence confirms that the stock is not in imminent danger of extinction' (NMFS 2016, p. 8). Until recently, marine mammal populations listed as threatened have been shown to be declining or depleted, and it appears that the default value for $F_{r}$ presumes this relationship. Unlike most ESA listings, the ringed and bearded seal listings did not identify, or depend on, a population decline. Instead, the listings for bearded and ringed seals were based on predicted population declines within the subsequent $100 \mathrm{yr}$ based on how each species would respond to changes in environmental factors (e.g. decreased sea ice and snow deposition) predicted by climate models, but without consideration of the current status or trend of each population. The ringed and bearded seal listing decisions represent a new class of listings that re- quire unique treatment when setting default values for calculating PBR. Therefore, a review of the recovery factors (i.e. $F_{r}$ ) used when calculating PBR for ice seals, keeping in mind that ice seals are an important subsistence resource and that no stock is in imminent danger of extinction, appears to be warranted.

\subsection{Recommendations}

Because most human-caused removals of ice seals are a result of subsistence harvests, maintaining harvest monitoring programs in Alaska is paramount for assessing sustainability. Our experience estimating harvest plus struck and lost should be used to improve future estimates of subsistence removals for evaluating sustainability.

\subsubsection{Community surveys}

A comprehensive state-wide survey strategy should be developed to estimate the number of seals removed for subsistence annually and to quantify inter-annual variability and trends. To quantify variability, this strategy should (1) survey more communities, (2) survey the same communities in several consecutive years, and (3) collect struck and lost information. For example, one-third of all communities could be surveyed for 3 consecutive years, and then those communities would be surveyed again 10 yr later. Such a schedule would provide consistent monitoring for some communities within each region, in any given year, and would include all communities on a 10 yr rotation. The highest priority region for additional surveys is AVCP because it has the most seal hunting communities and the fewest community surveys.

Harvest surveys should be coordinated among entities conducting surveys (e.g. NSB, ISC, BBNA, State of Alaska). Results should be presented with clear and complete methods to ensure that harvest data are used appropriately, including (1) how households were selected, (2) what proportion of all households were surveyed, (3) how extrapolations were calculated, and (4) how struck and lost was counted.

\subsubsection{Struck and lost}

Clearly, more effort is needed to quantify struck and lost, how best to report it, and what measures can be taken to reduce it. Such research will require 
collaboration with hunters, community leaders, the ISC, and managers to identify an approach that will provide species-specific estimates of struck and lost that are acceptable to hunters and managers.

\subsubsection{Seal abundance estimates}

In addition to the need for continued harvest monitoring, improved estimates of seal population abundance would increase confidence that removals are sustainable. Increased precision in seal abundance drives $N_{\min }$ upward, increasing PBR and providing a stronger basis for managers to choose less conservative values for $F_{r}$, which also increases PBR.

\section{CONCLUSIONS}

Given the high degree of conservatism built into our analysis, we conclude that the subsistence removals including seals struck and lost are sustainable for all 4 species of ice seals in Alaska. Our analysis of harvest trend indicates that for most communities the subsistence removal of ice seals has remained relatively stable since 1992. The only significant trends in subsistence removal were negative. Therefore, we think it likely that subsistence hunting of ice seals will remain sustainable unless large increases in harvests or struck and lost occur concurrent with decreases in population abundance.

Acknowledgements. The ISC is instrumental in the collection of harvest information, especially in the AVCP region. Former ISC members that deserve special mention for their dedication to better subsistence harvest numbers include John Goodwin, Molly Chythlook, Enoch Shiedt, Austin Ahmasuk, and Sandy Tahbone. Current ISC members include Billy Adams, Taqulik Hepa, Cyrus Harris, Brandon Ahmasuk, Benjamin Payenna, Albert Simon, Jennifer Hooper, Helen Aderman, Sam Gosuk, and Emerson Moto; Executive Director Michael Pederson. The past and current commitment of these individuals to collecting subsistence harvest information in Alaska is critical for ice seal management and understanding the importance of ice seals to Alaskan Natives. Community harvest surveys are time intensive and we recognize the hard work by surveyors and participants; without their efforts this project would not be possible. We thank our reviewers, whose comments greatly improved the manuscript, including Drs. James Fall and John Citta for comments on an early version, and are grateful to Kathy Frost and 3 anonymous reviewers for comments resulting in the final manuscript. Funding for recent surveys and these analyses were provided by a State Wildlife Grant, NMFS through the ISC, and NMFS Species Recovery Grants to States (Section 6 Program \#NA16NMF4720075).

\section{LITERATURE CITED}

Ahmasuk A (2006) A report on tests of .17 caliber and .22 caliber rimfire terminal performance in the harvest of ice seals, and in situ ballistics examination. Kawerak, Nome, AK

Ahmasuk A, Trigg E (2007) Bering Strait Region local and traditional knowledge pilot project: a comprehensive subsistence use study of the Bering Strait Region. Kawerak, Nome, AK

Bacon JJ, Hepa TR, Brower HK Jr, Pederson M, Olemaun TP, George JC, Corrigan BG (2009) Estimates of subsistence harvest for villages on the North Slope of Alaska, 1994-2003. North Slope Borough Department of Wildlife Management, Barrow, AK

* Barlow J, Swartz SL, Eagle TC, Wade PR (1995) US Marine mammal stock assessments: guidelines for preparation, background, and a summary of the 1995 assessments. NOAA Tech Memo NMFS-OPR-95-6. www.fisheries.noaa. gov/national/marine-mammal-protection/guidelinesassessing-marine-mammal-stocks

* Bates D, Maechler M, Bolker B, Walker S (2015) Fitting linear mixed-effects models using lme4. J Stat Softw 67: $1-48$

*Bengtson JL, Hiruki-Raring LM, Simpkins MA, Boveng PL (2005) Ringed and bearded seal densities in the eastern Chukchi Sea 1999-2000. Polar Biol 28:833-845

Boveng PL, Bengtson JL, Buckley TW, Cameron MF and others (2009) Status review of the spotted seal (Phoca largha). NOAA Tech Memo NMFS-AFSC-200

Boveng PL, Bengtson JL, Cameron MF, Dahle SP and others (2013) Status review of the ribbon seal. NOAA Tech Memo NMFS-AFSC-255

* Braem NM, Mikow E, Kostick ML (2017) Chukchi Sea and Norton Sound observation network: harvest and use of wild resources in 9 communities in Arctic Alaska, 20122014. Technical Paper No. 403. Alaska Department of Fish and Game, Division of Subsistence, Juneau, AK. www. adfg.alaska.gov/techpap/TP403.pdf (accessed August 2019)

Brown CL, Braem NM, Kostick ML, Trainor A and others (2016) Harvests and uses of wild resources in 4 interior Alaska communities and 3 Arctic Alaska communities, 2014. Technical Paper No. 426. Alaska Department of Fish and Game, Division of Subsistence, Juneau, AK. www.adfg. alaska.gov/techpap/TP426.pdf (accessed August 2019)

Burns JJ (1967) The Pacific bearded seal. Federal aid in wildlife restoration project report. Alaska Department of Fish and Game, Juneau, AK

Burns JJ, Frost KJ (1983) Natural history and ecology of the bearded seal, Erignathus barbatus. OCSEAP Final Rep 19:311-392

* Burnsilver S, Magdanz J, Stotts R, Berman M, Kofinas G (2016) Are mixed economies persistent or transitional? Evidence using social networks from Arctic Alaska. Am Anthropol 118:121-129

Cameron MF, Bengtson JL, Boveng PL, Jansen JK and others (2010) Status review of the bearded seal (Erignathus barbatus). NOAA Tech Memo NMFS-AFSC-211

* Coffing M, Scott CL, Utermohle CJ (1998) The subsistence harvest of seals and sea lions by Alaska Natives in three communities of the Yukon-Kuskokwim Delta, Alaska, 1997-98. Technical Paper No. 255. State of Alaska Department of Fish and Game, Juneau, AK. www.adfg. alaska.gov/techpap/tp255.pdf (accessed August 2019) 
Coffing M, Scott CL, Utermohle CJ (1999) The subsistence harvest of seals and sea lions by Alaska Natives in three communities of the Yukon-Kuskokwim Delta, Alaska, 1998-99. Technical Paper No. 257. State of Alaska Department of Fish and Game, Juneau, AK. www.adfg. alaska.gov/techpap/tp257.pdf (accessed August 2019)

Coiley-Kenner P, Krieg TM, Chythlook MB, Jennings G (2003) Wild resource harvests and uses by residents of Manokotak, Togiak, and Twin Hills, 1999/2000. Technical Paper No. 275. Alaska Department of Fish and Game, Division of Subsistence, Juneau, AK. www.adfg.alaska. gov/techpap/tp275.pdf (accessed August 2019)

Conn PB, Ver Hoef JM, McClintock BT, Moreland EE and others (2014) Estimating multispecies abundance using automated detection systems: ice-associated seals in the Bering Sea. Methods Ecol Evol 5:1280-1293

Crawford JA, Quakenbush LT, Citta JJ (2015) A comparison of ringed and bearded seal diet, condition and productivity between historical (1975-1984) and recent (20032012) periods in the Alaskan Bering and Chukchi seas. Prog Oceanogr 136:133-150

* Evans S, Kukkonen M, Holen D, Koster DS (2013) Harvests and uses of wild resources in Dillingham, Alaska, 2010. Technical Paper No. 375. Alaska Department of Fish and Game, Division of Subsistence, Juneau, AK. www. adfg.alaska.gov/techpap/tp375.pdf (accessed August 2019)

Fall JA (2014) Subsistence in Alaska: a year 2012 update. Alaska Department of Fish and Game, Division of Subsistence, Juneau, AK. www.adfg.alaska.gov/static/regulations/ regprocess/gameboard/pdfs/2013-2014/Statewide_03-1414/rcs/rc011_ADFG_Subsistence_Update.pdf (accessed August 2019)

Fall JA, Utermohle CJ (1995) An investigation of the sociocultural consequences of outer continental shelf development in Alaska. BOEM MMS 95-014 OCS study. Cooperative agreement No. 14-35-0001-30622. www.boem.gov/ BOEM-Newsroom/Library/Publications/1995/95_014.aspx (assessed August 2019)

Fall JA, Braem NM, Brown CL, Hutchinson-Scarbrough LB, Koster DS, Krieg TM (2013) Continuity and change in subsistence harvests in five Bering Sea communities: Akutan, Emmonak, Savoonga, St. Paul, and Togiak. Deep Sea Res II 94:274-291

Fay FH, Burns JJ, Stoker SW, Grundy JS (1994) The struck and lost factor in Alaskan walrus harvests, 1952-1972. Arctic 47:368-373

Fuller AS, George JC (1997) Evaluation of subsistence harvest data from the North Slope Borough 1993 census for eight North Slope villages: for the calendar year 1992. North Slope Borough Department of Wildlife Management, Barrow, AK

Georgette S, Coffing M, Scott CL, Utermohle CJ (1998) The subsistence harvest of seals and sea lions by Alaska Natives in the Norton Sound-Bering Strait Region, Alaska, 1996-97. Technical Paper No. 242. State of Alaska Department of Fish and Game, Juneau, AK. www.adfg. alaska.gov/techpap/tp242.pdf (accessed August 2019)

Holen D, Stariwat J, Kreig TM, Lemons T (2012) Subsistence harvests and uses of wild resources in Aleknagik, Clark's Point, and Manokotak, Alaska, 2008. Technical Paper No. 368. State of Alaska Department of Fish and Game, Juneau, AK. www.adfg.alaska.gov/techpap/TP\%20368.pdf (accessed August 2019)

* Huntington HP, Quakenbush LT, Nelson M (2017) Evaluat- ing the effects of climate change on indigenous marine mammal hunting in northern and western Alaska using traditional knowledge. Front Mar Sci 4:319

Ice Seal Committee (ISC) (2019) The subsistence harvest of ice seals in Alaska - a compilation of existing information, 1960-2017. Ice Seal Committee, Barrow, AK. www. north-slope.org/departments/wildlife-management/comanagement-organizations/ice-seal-committee\#Reports

* Ikuta H, Runfola DM, Simon JJ, Kostick ML (2016) Subsistence harvest in 6 communities on the Bering Sea in the Kuskokwim River drainage, and on the Yukon River, 2013. Technical Paper No. 417. Alaska Department of Fish and Game, Division of Subsistence, Fairbanks, AK. www.adfg.alaska.gov/techpap/tp417.pdf (accessed August 2019)

ISC \& NMFS (2006) Agreement between the Ice Seal Committee and the National Marine Fisheries Service for the co-management of Alaskan ice seal populations. www. north-slope.org/departments/wildlife-management/comanagement-organizations/ice-seal-committee (select Committee Documents, accessed August 2019)

Kawerak (2002) 2002 Bering Strait Region ice seal harvest survey. Kawerak, Nome, AK

Kelly BP, Bengtson JL, Boveng PL, Cameron MF and others (2010) Status review of the ringed seal (Phoca hispida). NOAA Tech Memo NMFS-AFSC-212

* Krafft BA, Lydersen C, Kovacs KM, Gjertz I, Hauge T (2000) Diving behaviour of lactating bearded seals (Erignathus barbatus) in the Svalbard area. Can J Zool 78:1408-1418

* Magdanz JS, Alexander C (1995) Bering Land Bridge 1995 Baseline harvest profile Noatak and Shishmaref, Alaska. Alaska Department of Fish and Game, Division of Subsistence, Juneau AK. www.adfg.alaska.gov/sb/CSIS/index. cfm?ADFG=harvInfo.harvestCommSelComm (search by community)

Magdanz JS, Utermohle CJ, Wolfe RJ (2002) The production and distribution of wild foods in Wales and Deering, Alaska. Tech Pap No. 259. Alaska Department of Fish and Game, Division of Subsistence, Juneau, AK. www.adfg. alaska.gov/techpap/TP259.pdf (accessed August 2019)

Magdanz JS, Braem NS, Robbins BC, Koster DS (2010) Subsistence harvests in Northwest Alaska, Kivalina and Noatak, 2007. Technical Paper No. 354. State of Alaska Department of Fish and Game, Division of Subsistence, Juneau, AK. www.adfg.alaska.gov/techpap/tp354.pdf (accessed August 2019)

Magdanz J, Koster DS, Naves L, Fox P (2011) Subsistence harvest in northwest Alaska, Buckland and Kiana, 2003 and 2006. Technical Paper No. 363. Alaska Department of Fish and Game, Division of Subsistence, Juneau, AK. www.adfg.alaska.gov/techpap/tp363.pdf (accessed August 2019)

Moore JE, Merrick R (eds) (2011) Guidelines for assessing marine mammal stocks: report of the GAMMS III Workshop, February 15-18, 2011, La Jolla, California. NOAA Tech Memo NMFS-OPR-47

Muto MM, Helker RP, Angliss RP, Allen BA and others (2018) Alaska marine mammal stock assessments, 2017. NOAA Tech Memo NMFS-AFSC-378

NMFS (2005) Revisions to guidelines for assessing marine mammal stocks. www.fisheries.noaa.gov/national/ marine-mammal-protection/guidelines-assessing-marinemammal-stocks

NMFS (2016) Guidelines for preparing stock assessment re- 
ports pursuant to the 1994 amendments to the MMPA. National Marine Fisheries Service Instruction 02-204-01. www. fisheries.noaa.gov/national/marine-mammal-protection/ guidelines-assessing-marine-mammal-stocks

NOAA (2012a) Threatened status for the Arctic, Okhotsk, and Baltic subspecies of the ringed seal and endangered status for the Ladoga subspecies of the ringed seal. Fed Regist 77:76706-76738

NOAA (2012b) Threatened status for the Beringia and Okhotsk distinct population segments of the Erignathus barbatus nauticus subspecies of the bearded seal. Fed Regist 77:76740-76768

* Quakenbush L, Taras M, Hooper J (2007) A student guide to seal hunting and safety. Ice Seal Committee and Imarpigmiut Ungungssiit Murilkestiit Hunters. www.north-slope. org/departments/wildlife-management/co-managementorganizations/ice-seal-committee (accessed August 2018)

Quakenbush L, Citta J, Crawford J (2009) Biology of the spotted seal (Phoca largha) in Alaska from 1962 to 2008. Preliminary report to National Marine Fisheries Service. www.adfg.alaska.gov/index.cfm?adfg=marinemammalprogram.icesealbio (accessed August 2018)

R Development Core Team (2018) R: a language and environment for statistical computing. R Foundation for Statistical Computing, Vienna

Shiedt E (2012) Report to the Ice Seal Committee on the harvest of ice seals in Deering, Noatak, Buckland, and Kivalina, Alaska during 2011. www.north-slope.org/ departments/wildlife-management/co-managementorganizations/ice-seal-committee (accessed August 2018)

Sjare S, Stenson GB (2002) Estimating struck and loss rates for harp seals (Pagophilus groenlandicus) in the northwest Atlantic. Mar Mamm Sci 18:710-720

Tahbone ST, Trigg EW (2011) 2009 Comprehensive subsistence survey Savoonga, Alaska. Final report to the North Pacific Research Board, Agreement NA07NMF4720082. Kawerak, Nome, AK

Wade PR (1998) Calculating limits to the allowable humancaused mortality of cetaceans and pinnipeds. Mar Mamm Sci 14:1-37

Wade PR, Angliss RP (1997) Guidelines for assessing marine mammal stocks: report of the GAMMS Workshop April 3-5, 1996, Seattle, Washington. Office of Protected Resources, NMFS. NOAA Tech Memo NMFS-OPR-12. www. fisheries.noaa.gov/national/marine-mammal-protection/ guidelines-assessing-marine-mammal-stocks (accessed August 2019)

Whiting A (2006) Native Village of Kotzebue Harvest Survey Program 2002-2003-2004. www.kotzebueira.org/programs/ environmental-protection.html (accessed August 2018)

Wolfe RJ (2001) The subsistence harvest of harbor seals and sea lions by Alaska Natives in 2000. Technical Paper No. 266. State of Alaska Department of Fish and Game, Division of Subsistence, Juneau, AK. www.adfg.alaska.gov/ techpap/tp266.pdf (accessed August 2019)

Wolfe RJ, Hutchinson-Scarbrough LB (1999) The subsistence harvest of harbor seals and sea lions by Alaska Natives in 1998. Technical Paper No. 250. State of Alaska Department of Fish and Game, Division of Subsistence, Juneau, AK. www.adfg.alaska.gov/techpap/tp250.pdf (accessed August 2019)

Wolfe RJ, Mishler C (1993) The subsistence harvest of harbor seals and sea lions by Alaska Natives in 1992. Technical Paper No. 229. State of Alaska Department of Fish and Game, Division of Subsistence, Juneau, AK. www. adfg.alaska.gov/techpap/tp229.pdf (accessed August 2019)

*Wolfe RJ, Mishler C (1994) The subsistence harvest of harbor seals and sea lions by Alaska Natives in 1993. Technical Paper No. 233. State of Alaska Department of Fish and Game, Division of Subsistence, Juneau, AK. www. adfg.alaska.gov/techpap/tp233.pdf (accessed August 2019)

*Wolfe RJ, Mishler C (1995) The subsistence harvest of harbor seals and sea lions by Alaska Natives in 1994. Technical Paper No. 236. State of Alaska Department of Fish and Game, Division of Subsistence, Juneau, AK. www. adfg.alaska.gov/techpap/tp236.pdf (accessed August 2019)

*Wolfe RJ, Mishler C (1996) The subsistence harvest of harbor seals and sea lions by Alaska Natives in 1995. Technical Paper No. 238. State of Alaska Department of Fish and Game, Division of Subsistence, Juneau, AK. www. adfg.alaska.gov/techpap/tp238.pdf (accessed August 2019)

*Wolfe RJ, Mishler C (1997) The subsistence harvest of harbor seals and sea lions by Alaska Natives in 1996. Technical Paper No. 241. State of Alaska Department of Fish and Game, Division of Subsistence, Juneau, AK. www. adfg.alaska.gov/techpap/tp241.pdf (accessed August 2019)

*Wolfe RJ, Mishler C (1998) The subsistence harvest of harbor seals and sea lions by Alaska Natives in 1997. Technical Paper No. 246. State of Alaska Department of Fish and Game, Division of Subsistence, Juneau, AK. www. adfg.alaska.gov/techpap/tp246.pdf (accessed August 2019)

WWolfe RJ, Scott C (2010) Continuity and change in salmon harvest patterns, Yukon River drainage, Alaska. Final Report to US Fish and Wildlife Service, Office of Subsistence Management, Fisheries Resource Monitoring Program Study 07-253. www.doi.gov/subsistence/frmp/ reports (accessed August 2019)

*Wolfe RJ, Fall JA, Stanek RT (2002) The subsistence harvest of harbor seals and sea lions by Alaska Natives in 2001. Technical Paper No. 273. State of Alaska Department of Fish and Game, Division of Subsistence, Juneau, AK. www.adfg.alaska.gov/techpap/tp273.pdf (accessed August 2019)

*Wolfe RJ, Fall JA, Stanek RT (2003) The subsistence harvest of harbor seals and sea lions by Alaska Natives in 2002. Technical Paper No. 277. State of Alaska Department of Fish and Game, Division of Subsistence, Juneau, AK. www.adfg.alaska.gov/techpap/tp277.pdf (accessed August 2019)

Wolfe RJ, Fall JA, Stanek RT (2004) The subsistence harvest of harbor seals and sea lions by Alaska Natives in 2003. Technical Paper No. 291. State of Alaska Department of Fish and Game, Division of Subsistence, Juneau, AK. www.adfg.alaska.gov/techpap/tp291.pdf (accessed August 2019)

Wolfe RJ, Fall JA, Stanek RT (2005) The subsistence harvest of harbor seals and sea lions by Alaska Natives in 2004. Technical Paper No. 303. State of Alaska Department of Fish and Game, Division of Subsistence, Juneau, AK. www.adfg.alaska.gov/techpap/tp303.pdf (accessed August 2019)

WWolfe RJ, Fall JA, Stanek RT (2006) The subsistence harvest of harbor seals and sea lions by Alaska Natives in 2005. Technical Paper No. 319. State of Alaska Department of 
Fish and Game, Division of Subsistence, Juneau, AK. www.adfg.alaska.gov/techpap/tp319.pdf (accessed August 2019)

Wolfe RJ, Fall JA, Riedel M (2008) The subsistence harvest of harbor seals and sea lions by Alaska Natives in 2006. Technical Paper No. 339. State of Alaska Department of Fish and Game, Division of Subsistence, Juneau, AK. www. adfg.alaska.gov/techpap/tp339.pdf (accessed August 2019)

Wolfe RJ, Fall JA, Riedel M (2009a) The subsistence harvest of harbor seals and sea lions by Alaska Natives in 2007.

Editorial responsibility: Rebecca Lewison,

San Diego, California, USA
Technical Paper No. 345. State of Alaska Department of Fish and Game, Division of Subsistence, Juneau, AK. www.adfg.alaska.gov/techpap/tp345.pdf (accessed August 2019)

Wolfe RJ, Fall JA, Riedel M (2009b) The subsistence harvest of harbor seals and sea lions by Alaska Natives in 2008. Technical Paper No. 347. State of Alaska Department of Fish and Game, Division of Subsistence, Juneau, AK. www.adfg.alaska.gov/techpap/tp347.pdf (accessed August 2019)

Submitted: September 5, 2018; Accepted: July 4, 2019 Proofs received from author(s): September 5, 2019 